\title{
Temperature Rising: Iran's Revolutionary Guards and Wars in the Middle East. By Nader Uskowi. Lanham, MD; Rowman \& Littlefield, 2019.
}

Mark Roberts

Follow this and additional works at: https://digitalcommons.usf.edu/jss

pp. $128-130$

\section{Recommended Citation}

Roberts, Mark. "Temperature Rising: Iran's Revolutionary Guards and Wars in the Middle East. By Nader Uskowi. Lanham, MD; Rowman \& Littlefield, 2019.." Journal of Strategic Security 13, no. 1 (2020) : 128-130.

DOI: https://doi.org/10.5038/1944-0472.13.1.1806

Available at: https://digitalcommons.usf.edu/jss/vol13/iss1/6

This Book Review is brought to you for free and open access by the Open Access Journals at Digital Commons @ University of South Florida. It has been accepted for inclusion in Journal of Strategic Security by an authorized editor of Digital Commons @ University of South Florida. For more information, please contact digitalcommons@usf.edu. 
Temperature Rising: Iran's Revolutionary Guards and Wars in the Middle East. By Nader Uskowi. Lanham, MD; Rowman \& Littlefield, 2019. 


\section{Temperature Rising: Iran's Revolutionary Guards and Wars in the Middle East. By Nader Uskowi. Lanham, MD; Rowman \& Littlefield, 2019. ISBN 978-1-5381-2173-3. Notes. Bibliography. Maps. Sources cited. Index. Pp. xvii, 207. \$42.oo.}

Temperature Rising examines the role of Iran's Islamic Revolutionary Guard Corps (IRGC) as it expands it influence in both external and internal roles. The book covers forty years of IRGC history and activities. This tome is a must read for Iran watchers and those seeking a better understanding of Iran's role in the region. The author is the son of an Iranian Imperial Army major general. He currently serves as a Senior Fellow at the Scowcroft Center for Strategy and Security at the Atlantic Council. He formerly served as a Senior Policy Advisor to the U.S. Central Command.

During his foreign exile in Iraq and France, Ayatollah Khomeini envisioned a "people's army" to help overthrow Shah Muhammad Reza Pahlavi. The Shah left Iran before Khomeini could establish such an entity. Upon assuming power, Khomeini ordered the creation of the IRGC to fulfill the "people's army" function. Internally, the IRGC served as guardians of the revolution to prevent U.S. or Shah-supported threat to the regime from challenging Khomeini's grip on power. Externally, the IRGC was Khomeini's force of shock troops to spread Islamic revolution throughout the Middle East. Khomeini sought to establish Iran as the regional power in not only the Persian Gulf, but the Middle East as well. He saw the IRGC as his principal means of attaining that goal.

Uskowi outlines how the IRGC came into its own during the brutal eightyear Iran-Iraq war, proving its valor in battle and learning valuable lessons in combat tactics and strategy. Khomeini came to rely on the IRGC more than the regular Iranian army. The IRGC's religious zeal cemented its role in preserving Khomeini's ideological vision of an Islamic republic. The war served to solidify its ideological commitment to Khomeini's brand of Shia Islam as a bastion of true Islam against both Sunni Islam and nonMuslims.

During this same timeframe, the IRGC helped found, train, and indoctrinate Lebanese Hizballah, Iran's staunchest Shia ally. These years shaped the IRGC into one of the most lethal terrorist groups in the world 
with a potent military capability. As the vanguards of the Islamic revolution, the IRGC's Quds Force (QF) became the lead tool to establish and expand a Shia arc of influence to help Tehran gain footholds in fellow Shia and weakened Sunni regimes in the region.

The author traces how the IRGC became the impetus behind a so-called Shia Liberation Army (SLA) that has mobilized, trained, and armed almost 200,000 fighters in Lebanon, Syria, Iraq, Afghanistan, and Yemen. The SLA, guided by the IRGC, serves as a mirror IRGC to safeguard and spread Shia ideology and goals in the Middle East.

Uskowi takes the reader on a tour through the IRGC's roles in the Arab Spring, its fight against the so-called Islamic State in Syria and Iraq, IRGC support for Houthis in Yemen, Iranian intrigues in western Afghanistan, and Iran's own internal political dynamic. Within Iran, the IRGC supports the Office of the Supreme Leader. As such, it controls the country's nuclear and ballistic missile programs. This span of control gives it more autonomy than other governmental organs with less accountability. Ideological zeal trumps bureaucratic competence.

The IRGC directs business enterprises through mega-foundations controlling over five hundred business enterprises. These financial structures make up roughly half of Iran's economy and have enriched senior IRGC officers through diversified business portfolios and selfaggrandizing deals. Some of the businesses are above board, while others are "off the books." This dynamic lends itself to more corruption and less accountability.

The IRGC's QF will continue to indoctrinate, train, and support Shia movements and militias barring regime change in Tehran. Its specialized units (armor, artillery, rockets, ballistic missiles, unmanned aerial vehicles, and special forces) deploy throughout the region to provide intelligence, logistics, and training to irregular and regular forces to wage conventional and hybrid warfare. With easy access to proxies and allies in Syria, Lebanon, Iraq, Afghanistan, and Yemen, the IRGC can project power well beyond Iran's territory, in fulfillment of Khomeini's vision of regional influence. 
Thirty years after Khomeini's death, his vision for the IRGC remains intact. Iran seeks to be a regional power and sees itself as such. Employing Khomeini's militant interpretation of Shia Islam, the IRGC has served an internal security organ, and an external expeditionary army.

Uskowi's book has a rightful place on the shelf of anyone studying terrorism, political violence, the Persian Gulf, the Middle East, and Iran. His keen insights and comprehensive examination of the IRGC skillfully outline the organization's impact on Iran and the region. This is one of the best books on the topic since Kenneth Katzman's The Warriors of Islam: Iran's Revolutionary Guard.

Mark Roberts 